\title{
Wirtualne sale i globalne sieci. Partycypacja w kulturze filmowej w kontekście pandemii
}

\section{Abstract \\ Virtual Screens, Global Networks. Film Culture Participation in the Wake of Pandemic}

The article discusses the subject of virtualization - the process of partial transmission significant discursive fields into the Internet - of the film culture, which is defined as the group of practices and discourses accompanying cinema, which connect it with the socio-cultural environment. According to the author, the virtualization process is specifically exposed during pandemics and social isolation, what is presented in the text from the perspective of film audience. Pandemic is treated here as liminoidal moment, in which, due to the disorder of cinema's functioning, its social networks happen to transform in certain manner. By interpreting results of his own fieldwork, author points at general dynamics of virtualization as an element of contemporary film culture, highlighting both the possibilities opened by such situation and dangers it brings.

Keywords: cinema, virtualization, film culture, locality, globalization

\section{Wrzuceni w kryzys}

Wiosną 2020 r. cały świat zatrzymał się w związku z globalną pandemią COVID-19 (tzw. koronawirusa). $\mathrm{Z}$ dnia na dzień zamrożone zostało codzienne funkcjonowanie wielu instytucji, usług czy procesów ekonomiczno-społecznych, a co za tym idzie - doszło do znaczącego wstrząśnięcia sieciami społecznych relacji (zob. Latour 2005: 71-72). W miarę rozwoju zdarzeń i kolejnych analiz środowiska na- 
ukowego szybko stało się jasne, że kryzysowa sytuacja będzie czymś więcej niż tylko chwilową niedogodnością, powodując, że społeczeństwa zmuszone będą do przeciągającego się utrzymywania tzw. rygorów sanitarnych, a działanie poszczególnych sfer gospodarki i życia społecznego (w tym sektora kultury) będzie na dłuższy czas zatrzymane. Nieuniknione było więc szybkie przekształcenie całej gamy społecznych praktyk czy też wytworzenie nowych w procesie pragmatycznej adaptacji do drastycznego ograniczenia możliwości bezpośredniego, osobistego kontaktu z drugim człowiekiem.

Choć może to zabrzmieć nieco niefortunnie, trudno nie zauważyć, że taka sytuacja $\mathrm{z}$ punktu widzenia nauk społecznych otwiera wyjątkowe perspektywy badawcze - będące równocześnie szansą, jak i wyzwaniem szybkiego, ale równocześnie refleksyjnego reagowania na dynamicznie zmieniającą się sytuację (Rabinow i in. 2008). Kontekst pandemii znacząco zmienił trajektorie procesów społecznych, wymuszając wielopoziomowe przeobrażenia sfery życia publicznego, ale także indywidualnych praktyk poszczególnych grup oraz jednostek, niejednokrotnie „,złapanych w ruchu” i raptownie zmuszonych do przemodelowania swojej codzienności. Ze względu na swoiste zawieszenie porządku rzeczywistości oraz fundamentalną niestabilność nowej, pandemicznej rzeczywistości do jej analitycznego ujęcia można zastosować wprowadzoną przez Victora Turnera kategorię liminoidalności (Turner 2005: 11-13), właściwy społeczeństwom przemysłowym (czy też poprzemysłowym) wariant fazy liminalnej rytuałów przejścia, charakteryzujący się otwartością zachodzących w nim procesów i swobodą poszczególnych jednostek-aktorów społecznych, których działania, wyjęte w quasi-liminalny sposób z regulujących życie społeczne norm i struktur, mają potencjał reformatorski, stanowiąc rodzaj tygla przeobrażającego rzeczywistość kultury (zob. Kafar 2002: 24-26).

$\mathrm{W}$ artykule proponuję antropologiczne spojrzenie na sytuację kryzysową w obrębie świata filmu. Jest to jeden z sektorów życia kulturalnego ${ }^{1}$, który został w dotkliwy sposób „zaatakowany” przez pandemiczny paraliż. Reżim izolacji zburzył niemalże wszystkie fundamenty, na których opierała się aktywność w tej sferze - przekreślone zostały repertuary, runęly harmonogramy premier, przeglądów, w miarę przedłużania się izolacji lista odwołanych wydarzeń i skutków zamrożenia rosła. Wytworzyło to w obrębie środowiska filmowego utrzymującą się kilka miesięcy sytuację walki o przetrwanie i prób odnajdywania się w nowej, nieoczekiwanej rzeczywistości, w której nie funkcjonują kina i nie mogą odbywać się żadne wydarzenia - od seansu filmowego do festiwalu. Traktując pandemię jako czynnik wywołujący w tym wycinku sieci społecznych relacji fazę liminoidalnego zawieszenia pomiędzy, przyjrzę się strategiom i percepcjom uczestników

${ }^{1}$ Dla jasności wywodu będę stosował rozróżnienie między przymiotnikami „kulturalny” i „kulturowy", przy czym pierwszy używany będzie w odniesieniu do tzw. wąskiej definicji kultury jako sfery aktywności duchowej i kreatywnej człowieka, drugi zaś stanowić będzie odwołanie do rozumienia szerokiego kultury jako ogółu ludzkich zachowań, symboli i organizacji społecznej. 
okołokinowego życia społecznego, poszukując w tej sferze realizacji procesów konstytuujących współcześnie kino jako aktora społecznego i charakteryzujących jego dynamikę. Przyjrzę się tej sytuacji z perspektywy widzów, a właściwie ich określonego typu, który można nazwać „widzami zaangażowanymi” - czyli obudowujących swój odbiór kina ogólnym zorientowaniem w dyskursie okołofilmowym, co przekłada się na „świadomy” wybór seansów².

\section{Kultura filmowa}

Prezentowane spojrzenie na film wyrasta $\mathrm{z}$ zainteresowania nim jako przestrzenią społeczną, rozwijanego w toku prowadzonych od 2019 r. badań etnograficznych ${ }^{3}$. W tej perspektywie kino nie jest jedynie dziedziną sztuki czy rozrywki, ale pewną instytucją społeczną, w skład której oprócz samych filmów wchodzą także egzystujące w rozmaitych kontekstach społecznych organizacje oraz mniej lub bardziej zwarte zbiorowości - widzów, krytyków, pracowników itd. Dla tych ludzi kino jest swego rodzaju rdzeniem, punktem orientacyjnym, wokół/względem którego organizują się - w mniejszym lub większym zakresie - życiowe praktyki, identyfikacja/tożsamość uczestnika życia społecznego, a czasem postrzeganie kultury i świata. Taki wycinek społeczeństwa (niebędący domkniętą i hegemoniczną dla jego uczestników monokulturą, ale jedną z przestrzeni realizacji siebie jako jednostki społecznej), nazywam roboczo „kulturą filmową”, nawiązując do rozumienia tego terminu przez Kazimierza Żygulskiego (1970), jako „całoś[ci], wliczając do niej zarówno utwory sztuki filmowej, [jak i] [...] bezpośrednie tworzenie, oddziaływanie, funkcjonowanie dzieła filmowego, które jest w centrum kultury filmowej, zjawiska towarzyszące temu dziełu, jak i elementy drugo- czy trzeciorzędne pozostające w pewnej odległości od dzieła filmowego", oraz Graeme’a Turnera, który postrzega kulturę filmową jako ogół tworzonych wokół filmu relacji wiążących ze sobą film, kulturę i ideologie (Turner 1999: 154, 160), przy czym to ujęcie

${ }^{2} \mathrm{~W}$ rozmowach na temat tego rodzaju zaangażowania powraca głównie jego opozycyjność do „widzów multipleksowych”, wybierających aktualnie reklamowane tytuły i niepoświęcających czasu na lektury na temat kina czy śledzenie bieżących informacji. To przeciwstawienie jest rodzajem wykorzystywanego przez wielu widzów zaangażowanych konstruktu podkreślającego na bazie kontrastu ich własną, bardziej „świadomą” tożsamość wobec kina.

${ }^{3}$ Omawiane badania składają się z bezpośredniego uczestnictwa w wybranych festiwalach filmowych (MFF Nowe Horyzonty i American Film Festival we Wrocławiu, Kamera Akcja w Łodzi oraz MFF w Berlinie), gdzie prowadziłem obserwację uczestniczącą oraz liczne rozmowy. Moje badania są zorientowane na analizę zakorzenionego w konkretnych aktywnościach dyskursu i związanych $\mathrm{z}$ nim praktyk. $\mathrm{Z}$ tego względu badania mają charakter niejednorodny $\mathrm{w}$ aspekcie terenu poznawanego etnograficznie. Klasyczna etnografia oparta na uczestnictwie w wydarzeniach i osobistym kontakcie z ludźmi w terenie jest w tym przypadku uzupełniana o równoległe działania netnograficzne (m.in. interakcje online) oraz ciągłą obserwację kultury filmowej z perspektywy widza i krytyka, co wprowadza do całości badań element autoetnograficzny (por. Ellis i in. 2011). 
łączę z kategorią pola Pierre’a Bourdieu (2007) i traktuję jako specyficzny byt, konstytuowany przez zespół praktyk i dyskursów, które wpisującą kino w tkankę życia społeczno-kulturowego. Pisząc o kinie, mam więc na myśli centralnego aktora pewnej sieci relacji, wokół którego organizują się rozmaite praktyki, dyskursy i procesy, składające się na rozumianą w proponowany tu sposób kulturę filmową.

Używam tu określenia „praktyki wobec kina” oznaczającego uczestnictwo w tej przestrzeni życia społecznego, przy czym wyróżniony przysłówek określa zorientowanie mentalne jednostek tworzących quasi-społeczność, którą na podstawie dotychczasowych badań uważam za zawiązującą się przez powiązanie aktywności z centralną instytucją-podmiotem-aktorem. Ujmując to nieco inaczej, funkcjonując w przestrzeni kultury/społeczeństwa, kino - zjawisko społeczne konstytuowane przez dzieła filmowe (Turner 2002: 1-2), podmioty prawne, ludzkie i technologiczne towarzyszące ich powstawaniu i rozpowszechnianiu oraz tworzone przez te podmioty sieci zależności na skalę lokalną, regionalną i globalną - jest aktorem, który tworzy elastyczną ramę dla ludzkich aktywności związanych z życiem zawodowym, uczestnictwem w wydarzeniach, identyfikacją i korzystaniem z określonej oferty kulturalnej. Te różne rodzaje aktywności, wpisując się w przestrzeń zakreślaną przez działanie kina-aktora, tworzą niejednorodny zbiór działań i zachowań, których wspólną cechą jest rodzaj odniesienia do samego kina na poziomie praktyki i/lub postrzegania swojej własnej osoby w pewnym kontekście społecznym.

Zdaję sobie sprawę, że proponowana kategoria kultury filmowej może wydawać się dość efemeryczna. To przestrzeń heterogeniczna, obejmująca dyskursy i praktyki o różnym profilu oraz intensywności. Tworzona w jej obrębie społeczność z kolei jest $\mathrm{z}$ gruntu niejednorodna i w zasadzie trudno mówić o jednej, fundamentalnej wspólnocie w ramach przestrzeni społecznej kina. Zamiast tego proponuję więc inkluzywne postrzeganie społeczności kinowej według kryterium podejmowania aktywności wobec kina. Jak sądzę, pozwala to na uniknięcie pułapek dogmatycznego klasyfikowania i doszukiwania się trwałej struktury tam, gdzie powinniśmy rozpatrywać bardziej tymczasowe i płynne kłącza powiązań i wielowątkowych odniesień (Latour 2005). Tworzona wokół filmu wspólnota ma wymiar przygodny i składa się z wielu zróżnicowanych wariantów praktyk, $\mathrm{z}$ analizy których wyłonić się może całościowa charakterystyka pola. W tym miejscu chciałbym skupić się na perspektywie jednej grupy, którą można uznać za fundamentalną dla zaistnienia społecznego wymiaru funkcjonowania kina, czyli widzów, a konkretniej widzów zaangażowanych. Ich perspektywa wydaje mi się szczególnie interesująca na tym etapie rozważań, ponieważ praktyki tej grupy cechują się z jednej strony pewnym szczerym entuzjazmem w stosunku do kina (nawet jeśli dane osoby są związane zawodowo z kinem, to nie traktują go „tylko czy nawet w pierwszej kolejności” jako pracy), z drugiej zaś wykazują zasadniczą refleksyjność zarówno wobec swoich zachowań, jak i przestrzeni społecznokulturowej, w której uczestniczą. Wypadkową tych dwóch cech widzów zaanga- 
żowanych jest relatywnie organiczny charakter ich perspektywy - mniej uwikłanej w profesjonalne sieci uwarunkowań ekonomicznych ${ }^{4}$ (na poziomie praktyk wobec kina), a równocześnie wyczulonej na zmiany procesów i relacji wewnątrz kultury filmowej. Ich spojrzenie dostarcza wglądu w warstwy relacji społecznych tworzonych wokół kina zasadzające się na bezpośredniej aktywności pojedynczych osób wobec tego aktora społecznego.

Jednym z najbardziej niejednoznacznych aspektów tak rozumianej kultury filmowej jest jej przestrzeń, a co za tym idzie, teren badań etnograficznych. Kultura filmowa jednocześnie jest zakorzeniona w konkretnych lokacjach, wokół których nawarstwiają się praktyki społeczne, jak i ową lokalność przekracza. Osadzanie dyskursów w miejscach takich jak lokalne kina studyjne czy festiwale czyni z lokowanych tam aktywności nośniki znaczeń i kontekstów związanych z filmem ważnych dla kina, które

ma znaczenie nie tylko jako coś, co się ogląda, ale też jako miejsce. Ważne jest pójść do przestrzeni, usiąść w swoim ulubionym fotelu czy wybrać tę kameralną salę, w której zawsze siedzę w pierwszym rzędzie, a czasem umówić się z koleżankami pod takim Muranowem czy Nowymi Horyzontami we Wrocławiu ${ }^{5}$.

Na to nakłada się z kolei odlokalnienie kina, zasadzające się na globalnym potencjale filmu (Hansen 2012: 16-17) - w przeciwieństwie do innych sztuk możliwego do masowego i identycznego kopiowania w celu rozprzestrzeniania tej samej formy dzieła na całym świecie, a także stosunkowo łatwego do translacji. Stwarza to dogodne warunki do odrywania się dyskursu od konkretnych miejsc organizujących doraźne praktyki społeczne i transmitowania aktywności do przestrzeni wirtualnej, w której mogą się wytwarzać relacje przekraczające geograficzne usytuowanie, dzięki czemu kultura filmowa może obfitować w nieoczywiste konfiguracje powiązań swoich uczestników, przykładowo wytwarzających silne zażyłości lub wręcz mikrospołeczności na odległość wielu tysięcy kilometrów. W kontekście funkcjonowania nowych mediów i globalizacji rynku w sferze marketingu, publicystyki i ram działalności filmowców można już w zasadzie mówić o ukonstytuowaniu się sfery internetu jako pełnoprawnej przestrzeni dyskursywnej, która jest pod względem intensywności i skomplikowania równorzędna tej realnej osadzonej w materialności kina jako miejsca spotkań i kontaktów społecznych.

${ }^{4}$ Przez silne uwikłanie rozumiem np. sprawczość na poziomie strukturalnym w branży (np. redaktorzy naczelni mediów, dyrektorzy, menedżerowie). W grupie spotkanych przeze mnie na tym etapie widzów zaangażowanych znaleźli się ludzie, którzy związki z kinem definiują przede wszystkim na poziomie pasji, a dopiero potem - ewentualnie - aktywności zawodowej.

${ }^{5}$ Rozmowa z Karoliną, absolwentką filmoznawstwa i regularną uczestniczką festiwali Nowe Horyzonty oraz American Film Festival we Wrocławiu, Warszawskiego Festiwalu Filmowego i łódzkiego Transatlantyku, przeprowadzona w listopadzie 2019 r. we Wrocławiu. 
W tym świetle przestrzeń kultury filmowej (por. Gupta, Ferguson 1997) należałoby postrzegać jako hybrydową, rozpiętą pomiędzy lokalnością praktyk widzowskich i wirtualizowanymi ${ }^{6}$ praktykami dyskursywnymi. Choć na podstawowym poziomie obydwie te sfery byłyby raczej komplementarne, pandemia i odcięcie wymiaru lokalno-materialnego polaryzuje ten podział, prowadząc do częściowego „pożerania” zamrożonej lokalności przez prężną wirtualność. Sam proces wirtualizacji jest zresztą pochodną globalizacyjnych tendencji filmu, wpisanych w samą istotę kina jako globalnej, masowej rozrywki (Adorno 1990), a także immanentnie technologiczny charakter filmu (Hansen 2012: 39-45, por. Kracauer 2012). Przyspieszenie tej tendencji w trakcie pandemicznej izolacji czy też, mówiąc bardziej plastycznie, owo „pożeranie” lokalnego charakteru praktyk kultury filmowej można postrzegać jako eskalację tendencji globalizujących (Harvey 2008). Właśnie tę właściwość zarysowanej w powyższy sposób przestrzeni badawczej chciałbym zgłębić, opierając się na „etnografii pandemii”. Perspektywa widzów pozwala uchwycić proces wirtualizacji dyskursów okołofilmowych na poziomie fundamentalnego działania na linii człowiek-film i dostrzec w opisywanych najczęściej z perspektywy medioznawczej (prymarnie zorientowanej na pojmowaną odgórnie branżę) zagadnieniach istotny wymiar społeczny.

\section{Kultura filmowa w pandemii}

Probierzem rozwoju pandemii w odniesieniu do środowiska filmowego jest sytuacja MFF w Cannes, który miał się odbyć tradycyjnie w maju. W momencie marcowej eksplozji koronawirusa w Europie, kiedy większość państw podjęła decyzje administracyjne o wprowadzeniu zasad społecznej izolacji i tymczasowym zamknięciu większości instytucji oraz obiektów kulturalnych, organizatorzy francuskiego festiwalu pewnie stali na stanowisku, że 73. edycja odbędzie się w planowanym terminie. Nieco później dyrekcja imprezy wydała komunikat informujący o planowanym przesunięciu terminu na przełom czerwca i lipca (Stolworthy 2020), by w końcu ogłosić, że festiwal w tym roku nie odbędzie się w tradycyjnej formie, organizatorzy badają możliwości alternatywnych rozwiązań (Pulver 2020), a do końca maja jedyną pewną informacją jest ogłoszenie w czerwcu 2020 r. listy filmów wyselekcjonowanych do udziału w tegorocznych sekcjach ${ }^{7}$. Przykład Cannes pozwala zorientować się w niestabilnej sytuacji kina

${ }^{6}$ Pojęcie to stosuję w korespondencji z medializacją rzeczy w rozumieniu S. Lasha i C. Lury, jako rodzaj uściślenia procesu wpisywania realności produktów kultury w sferę wirtualną, zapośredniczaną przez media (por. Lash, Lury 2011: 260-263).

7 Jest to istotne w kontekście funkcjonowania rynku filmowego - kwalifikacja do konkursu jest rodzajem znaku jakości, który dystrybutorzy i producenci wykorzystują do promocji i wzmacniania pozycji filmów (oraz swojej). Na poziomie widowni ometkowanie filmu przez tej rangi festiwal jest traktowane jako wskazówka, wedle której można się orientować w odniesieniu do setek premie- 
w czasie pandemii. Ograniczenie funkcjonowania kin oraz imprez, stanowiących fundament aktywności społecznych zorientowanych wokół filmu, wytworzyło liminoidalną sytuację kultury filmowej zawieszonej w niepewności pomiędzy dotychczasowym trybem funkcjonowania a trudną do przewidzenia przyszłością z coraz wyraźniejszym widmem kryzysu ekonomicznego oraz potencjalnym upadkiem poszczególnych firm czy instytucji radykalnie odciętych od przychodów.

Kontekst ten postrzegam nie tyle jako wyjęty z właściwego porządku rzeczy, ile jako będący rodzajem tymczasowego (ciągle się zmieniającego i niedomkniętego) przetworzenia rzeczywistości. Wpisuje się to w dynamiczną perspektywę rozumienia i analizowania kultury jako efektu zależności i oddziaływań rozpiętych w czasie i przestrzeni, co „prowadzi nieuchronnie do badania symboli, znaków, sygnałów oraz ich realizacji, werbalnych i niewerbalnych, które ludzie wykorzystują do osiągnięcia celów osobistych i grupowych" (Turner 2005: 27), przy czym triadę „symbol, znak, sygnał” należałoby tu utożsamić ze społecznymi znaczeniami i tożsamościami wytwarzanymi wobec kina. Uznanie ciągłości sytuacji kultury filmowej w czasie pandemii pozwala wpisać ją w szerszą dynamikę, dla której jest szczególnym wydarzeniem, kształtowanym przez przetwarzanie istniejących wcześniej kontekstów. Tak postrzegana pandemia staje się w optyce etnograficznej złożoną sytuacją, z której wyłania się obraz kultury filmowej poddanej „kryzysowej weryfikacji”, do pewnego stopnia odsłaniając formację, dynamikę i logikę przeobrażania różnych tworzących kulturę filmową dyskursów.

Przyjęcie perspektywy widzów prowadzi do wyeksponowania procesów pragmatyki społecznych dyskursów i identyfikacji wobec zjawiska, jakim jest kino, które opierają się przede wszystkim na zaangażowaniu ludzi, wpisujących się w ramy wyznaczane przez instytucje, i które stanowią z antropologicznej perspektywy istotę zjawisk, które staram się zbadać. Oddziaływania występujące wokół kina nieodmiennie sprowadzają się do gry z percepcją widza, często postrzeganego jako naturalny element mechaniki branży. Moim założeniem jest odwrócenie tej optyki i spojrzenie na kulturę filmową w taki sposób, w jaki wyłania się ona dla pojedynczych wchodzących z nią w kontakt jednostek.

Zamknięcie kin oznacza zablokowanie dostępu aktywności, będących „jednym[i] z najistotniejszych sposobów spędzania czasu” dla wielu osób określających się jako kinomani. Wymusiło to zmianę sposobu realizacji pasji mającej też często wymiar kreowania swojej tożsamości, opierającej się na poczuciu przy-

rowych tytułów - znaki poszczególnych sekcji festiwalu, np. Cannes, komunikują charakter filmu oraz spełnianie przez niego umownego minimum jakości, co lokuje go w przestrzeni dostrzegalnej świata filmu, odróżniając od setek pozycji pozbawionych takiego wyróżnika (jak również służy do stratyfikacji prestiżu - filmy metkowane przez festiwale w Cannes czy Wenecji dysponują większym wyjściowym kapitałem symbolicznym i rozpoznawalnością niż te ze znakiem jakości mniejszych imprez).

${ }^{8}$ Rozmowa z Agatą, regularną uczestniczką festiwalu Nowe Horyzonty, przeprowadzona zdalnie w kwietniu. 
wiązania do czynności świadomego wyboru oglądanych filmów i uczestnictwa w konkretnych wydarzeniach o tematyce filmowej. Tendencją, którą pandemia koronawirusa $\mathrm{z}$ pewnością wyeksponowała, jest silne przywiązanie zaangażowanych grup widowni do aktywności w ramach kultury filmowej. Jak stwierdziła jedna z moich rozmówczyń:

Zupełnie mi to przewraca moje bycie widzką, ale przez myśl mi nie przeszło nagle, że teraz coś się kończy, że przestaję żyć, oddychać kinem; [...] siedząc w domu co chwila, kilka razy dziennie wchodzę na strony czy profile kin, z którymi się czuję związana, przeglądam te rzeczy online, które gdzieś mam pozapisywane, czy które się pojawiają teraz jako „zostań w domu”. Bo po prostu bez tego mi jest trudno wyobrazić sobie swoje życie na tym etapie ${ }^{9}$.

$\mathrm{W}$ tej wypowiedzi wybrzmiewają dwie bardzo istotne kwestie. Po pierwsze, uświadomiona potrzeba odbioru filmów, która jest na poziomie samookreślenia (a także, co odczytać można u większości osób - sformatowania relacji z innymi ludźmi), po drugie zaś, niemal automatyczne przeniesienie aktywności do internetu. Dalej pada stwierdzenie:

Do tej pory Netflixa używałam jako taki dodatek i chyba częściej na jakieś seriale, oglądane do gotowania [...] niż pełnometrażowe filmy. [...] W izolacji, to zaczęłam scrollować bibliotekę i faktycznie, obejrzałam już kilka filmów, [...] [z]mobilizowałam się w końcu na MUBI i faktycznie teraz oglądam tam filmy co kilka dni [...], więc ogólnie może oglądam nawet więcej, niż normalnie, $\mathrm{z}$ chodzeniem do kina ${ }^{10}$.

Wątek streamingu i zasobów internetowych, które w czasie zamknięcia kin stały się nie alternatywnym, ale jedynym dostępnym medium dla widzów pragnących kontaktu z filmem, jest czymś, czemu warto poświęcić szczególną uwagę. Mówimy tu bowiem o odsłonięciu bardzo ważnego aspektu współczesnej, zapośredniczanej przez nowe technologie, kultury filmowej. Wirtualny obieg filmowy stał się dla widzów swoistym wybawieniem przy braku dostępu do kina, niejednokrotnie wzmacniając intensywność kontaktu z nim. Nie jest to zjawisko, które nagle pojawiło się w życiu kinomanów i kinomanek wraz z nastaniem pandemii - zwrot ku streamingowi istniał już wcześniej ${ }^{11}$, w izolacji uległ jednak eskalacji. Jeśli przyjrzymy się stosunkowi widzów do częściowego przenoszenia się znacznych obszarów dyskursywnych do internetu, dojdziemy do istoty tego procesu,

9 Rozmowa z Darią, regularną uczestniczką festiwali, związaną też z kilkoma DKF-ami. Prezentowane wypowiedzi są złożeniem $\mathrm{z}$ dwóch rozmów, prowadzonych $\mathrm{w}$ odstępnie 3 tygodni w kwietniu i maju.

${ }^{10}$ Netflix to najpopularniejsza platforma streamingowa, utożsamiana z rozwojem tego sektora branży. MUBI to serwis streamingowy sprofilowany na ambitne kino spoza głównego nurtu, oferujący rotacyjnie zmieniającą się ofertę 30 tytułów.

${ }_{11}$ Od kilku lat platformy streamingowe rosną w siłę jako gracz na rynku filmowym, który częściowo rywalizuje o widzów z kinami, jednak bardziej zapełnia niszę obiegu filmów, które zeszły już z ekranów lub nie dostały się na nie w dystrybucji klasycznej. 
mającego niebagatelne znaczenie dla współczesnej tożsamości kina jako aktora społecznego.

\section{Wirtualizacja i globalizacja}

Wirtualizacja kultury filmowej, związana z silnym przeniesieniem się wielu aktywności do internetu, wydaje się głównym wyznacznikiem trajektorii, jaką obiera kino w trakcie pandemii COVID-19, szczególnie jeśli weźmie się pod uwagę głosy takie jak Roberta ${ }^{12}$, który stwierdza:

Streaming pokazuje, że jednak jest fajną alternatywą dla kin. [...] Bo film to [...] żywe medium - kiedyś było kino nieme, wszedł dźwięk, potem kolor, pojawiła się telewizja, nośniki VHS, DVD... Streaming to [tylko] kolejny etap rozwoju, nowy kanał, który teraz, kiedy właśnie [zamknięto] kino, [p] okazuje jak jest świetny - można oglądać w domu i bazy są ciągle poszerzane, są nowości itd.

Faktycznie można uznać rozwój (przyspieszony dodatkowo izolacją) streamingu i modelu odbioru online za szansę na dostęp do szerszej oferty kulturalnej niż w wymagającym fizycznego przemieszczenia się modelu tradycyjnym. Zamknięci w domach widzowie zyskali dzięki instytucjom (dla których była to też forma walki o przetrwanie lub utrzymania wokół siebie społeczności sympatyków) możliwość odbioru znacznie wzbogaconej oferty. W tym sensie zamknięcie kulturalne w pandemii zadziałało jak katalizator dla zwiększania dostępności oferty kulturalnej za pośrednictwem internetu. Idąc tym tropem, można stwierdzić, że streaming i rosnące znaczenie przestrzeni wirtualnej w funkcjonowaniu kina jako aktora społecznego jest kontynuacją - według szkoły frankfurckiej od zarania właściwej technice filmowej - drogi przekształcania realnego przedmiotu w medialny obraz (zob. Lash, Lury 2011: 143-146), przy czym o ile samo medium filmowe jest „ruchomym cięciem trwania [przedstawianego] przedmiotu” (tamże: 175), o tyle wirtualizacja dodaje kolejny poziom zapośredniczenia i dokonuje nadbudowania filmu, przeniesionego $\mathrm{z}$ poziomu technicznie kreowanego i reprodukowanego „specjalnego modelu rzeczywistości” (Kracauer 1997: 46) do wymiaru upowszechnionego, uwolnionego od materialności produktu, który wpisany jest w globalną sieć komunikacji. Rodzi się tu pytanie, jakie tendencje będą się wyłaniać z liminoidalnej rzeczywistości, w którą wrzuceni zostali widzowie zmuszeni do raptownego przerzucenia swojej aktywności okołofilmowej do przestrzeni wirtualnej. Na pewnym poziomie działa to na korzyść odbiorców, którym umożliwia się dostęp do filmów z domu i zaciera część barier uniemożliwiających partycypację (np. limity miejsc czy jednostkowe zlokalizowanie rzadszych pokazów). Czyni to jednak kino szczególnie podatnym na globalizację i dyktat

${ }^{12} \mathrm{Z}$ wykształcenia informatyk, związany $\mathrm{z}$ kilkoma projektami filmowymi i regularnie uczestniczący m.in. w festiwalu Nowe Horyzonty oraz Camerimage w Krakowie, rozmowa z maja. 
korporacyjnej technologii, wypierającej bardziej lokalne, niemasowe modele partycypacji. Zwirtualizowane kino ${ }^{13}$ staje się coraz bardziej alienowane od kontak$\mathrm{tu}$, potencjalnie zawężone do jednostkowego zetknięcia widza $\mathrm{z}$ ekranem. To, co dotąd było jednym z modeli działania, stało się podczas pandemii praktycznie jedynym dostępnym sposobem obcowania $\mathrm{z}$ filmem; szczególnie wyraźne jest to w kontekście festiwali, wydarzeń z definicji społecznych - oglądanie filmów oznaczało „bycie z innymi ludźmi, spotkanie, wspólne stanie w kolejkach i poczucie, że jest się częścią jakiejś grupy"14. Model realizacji festiwali online ${ }^{15}$ odbiera ten społeczny aspekt wydarzenia, ograniczając je tylko do partykularnego odbioru dzieła. Jak mówi Agata:

Festiwal online to nie będzie to samo, przez brak kontaktu z innymi widzami, który jest akurat bardzo ważny, [...] chodzi o to, żeby mieć tę świadomość, że ci ludzie też tu przyszli, bo chcą zobaczyć to samo co ty, trochę się wtedy dzieli to doświadczenie - ja przynajmniej mam poczucie, że jest jakaś nić między nami.

Spragnieni tej wspólnotowości, widzowie wykorzystują więc kanał, który wcześniej służył im za przedłużenie bycia w kinie czyli fora internetowe i media społecznościowe, gdzie mogą wytworzyć zwirtualizowane relacje zastępcze względem fizycznego kontaktu ze współwidzami w kinach. Maciej stwierdzi1 ${ }^{16}$ :

Nie będzie kina bez kina. Nawet jak wszystko zamkną, bo wszyscy splajtują, rząd nie da kasy i cały rynek szlag trafi, to ludzie będą tworzyć jakieś kino, będą się spotykać. Już [teraz są przecież] wirtualne pokazy i ludzie się zbierają, łączą na Zoomie i Skype, oglądają razem. Osobno, ale razem. Bo o to tu chodzi i tego się nie zabierze. Nie będzie oglądania jeden na jeden, ja z ekranem. [...] Może po prostu przeniesiemy się z [„realu”] na „fejsa” - ale coś będzie.

Unikalność kina jako szeroko dostępnego medium przekłada się więc na stosunkowo lepsze warunki funkcjonowania branży w aspekcie finansowym, a co za tym idzie, społeczność kultury filmowej może względnie płynnie przechodzić do modelu partycypacji wirtualnej, a także całkiem swobodnie wytwarzać powią-

${ }^{13}$ W związku z przedłużającą się pandemią część kin studyjnych zdecydowała się na otworzenie wirtualnych sal w ramach modelu kina online. Pierwszym kinem w Polsce, które umożliwiło dostęp do repertuaru w tej formie, było krakowskie Kino Pod Baranami. W maju Stowarzyszenie Kin Studyjnych uruchomiło portal Moje E-Kino, będący wirtualną metainstytucją, w której wykupując dostęp online do filmów, widzowie mogą decydować, w jakim kinie chcą obejrzeć dany tytuł (wskazana instytucja otrzyma wpływ z zakupu biletu). Do programu przystąpiło ponad trzydzieści kin z całej Polski.

${ }^{14}$ Rozmowa z Agatą, na co dzień pracowniczką korporacji, regularnie jeździ na festiwale w Polsce, w przeszłości kilkukrotnie wolontariuszką na Nowych Horyzontach, przeprowadzona zdalnie w kwietniu.

${ }_{15}$ Pierwszym festiwalem, który zdecydował się na realizację wydarzenia w sieci, był kopenhaski CPH: DOX, a za jego przykładem poszły dalsze imprezy (Goi 2020). W Polsce pierwszymi festiwalami online były Wiosna Filmów (29.05-7.06) zrealizowany na platformie Moje E-Kino oraz Krakowski Festiwal Filmowy (31.05-7.06).

${ }_{16}$ Absolwent filmoznawstwa i krytyk, rozmowa prowadzona zdalnie w maju. 
zania i dyskursy o szerokiej skali przestrzennej, nieograniczonej do lokalnego produktu kulturalnego. Stosując obrazowy przykład:

Kino jest chyba ponadnarodowe $\mathrm{w}$ tym sensie, że nie ma tych ograniczeń do jednego miejsca. [...] W jakiś sposób to nas tak łączy na odległość, mam znajomych, z Azji i [Ameryki], z którymi widuję się na festiwalach, więc $\mathrm{w}$ sumie prawie ich przecież nie znam, nie byłem ani razu w kinie nawet, ale piszę do nich [...] a oni do mnie i przez cały rok rozmawiamy o kinie. I to jest coś fantastycznego, bo dzięki kinu my możemy mieć ze sobą te relacje. [...] A to by było niemożliwe, gdyby nie to, że możemy obejrzeć ten sam film $\mathrm{w}$ takiej samej formie $\mathrm{w}$ różnych miejscach na świecie ${ }^{17}$.

Odróżnia to tę konkretną branżę od innych dziedzin sztuki, również posiadających znaczenie kulturo- i grupotwórcze. Sytuacja wygląda odmiennie np. w przypadku teatru, który również oferuje repertuar online, przy czym „Forma zaangażowania [...] słabnie przy odbiorze rejestracji filmowej. [...] Rejestracje dokumentalne spektakli nie są przystosowane do pokazów publicznych, to często materiał roboczy [...], dla widza przed ekranem taki odbiór bywa męczący"18. W przypadku teatru zabranie czynnika bezpośredniego kontaktu jest bardziej dotkliwe, a branża musi sobie radzić $\mathrm{z}$ większym wyzwaniem niż kino ze względu na fakt, iż lockdown odbiera bezpośrednie spotkanie fizyczne, które jest istotą teatru.

Najistotniejsze wyróżniki kina - niebezpośredniość kontaktu twórców z widzami i potencjał reprodukcji oraz dystrybucji ponadlokalnej i ponadnarodowej - przekładają się na wysoką zdolność adaptacji do warunków izolacji. Tam, gdzie np. teatry ograniczone są do roboczych nagrań, branża filmowa ma do dyspozycji nieporównywalnie szerszy zbiór filmów w wersjach docelowych, które mogą być przesuwane pomiędzy kanałami dystrybucji, oferując zbliżone do kinowych standardy odbioru w wariancie online. Wirtualizacja kina może więc przebiegać bardzo sprawnie ze względu na to, że jest ono „elastyczne, masz kilka różnych modeli oglądania filmów i potencjalnie, dzięki internetowi może się branża obronić, wyjść jakoś bez upadku z tej całej epidemii, bo dosyć łatwo jest się dostosować po prostu do modelu oglądania czy upowszechniania, to nie zmienia nic w kinie jako takim"19. Ta elastyczność sprawia, że wielu widzów płynnie przechodzi na model partycypacji wirtualnej, co prowadzi z kolei do stymulacji rozwoju tej właśnie formy funkcjonowania wobec filmu. Seanse online są w obliczu niepewności związanej z pandemią COVID-19 pewniejszym kanałem dystrybucyjnym niż tradycyjne pokazy w kinach. Czyni to $\mathrm{z}$ nich dużo bezpieczniejszy wariant rozpowszechniania filmów, co może w dłuższej perspektywie czasowej przełożyć

${ }^{17}$ Rozmowa z Kubą, pracownikiem kina studyjnego, regularnym uczestnikiem festiwali, przeprowadzona w marcu w formie zdalnej.

${ }^{18}$ Rozmowa z Katarzyną, krytyczką teatralną i pracowniczką instytucji kultury teatralnej, przeprowadzona zdalnie w maju.

19 Rozmowa $\mathrm{z}$ Nikolasem, wolontariuszem na kilku międzynarodowych festiwalach, przeprowadzona zdalnie w kwietniu. Przekład własny z języka angielskiego. 
się na wzmocnienie pozycji przestrzeni wirtualnej w strukturze technologicznej branży filmowej ${ }^{20}$.

Zdecydowane tendencje wirtualizacyjne widoczne były w ostatnich latach, a można powiedzieć wręcz, że są one wpisane w charakterystykę kina jako instytucji społecznej (Hansen 2012). Pandemia koronawirusa stworzyła jednak warunki do przyspieszenia rozwoju tego procesu, który w związku z nagłą potrzebą zagospodarowania osieroconych przez instytucje potrzeb kinomanów stał się tymczasowo głównym modelem partycypacji w kulturze filmowej. Prawdopodobne jest, że nie będzie to wzmocnienie jedynie chwilowe - wielu widzów zdążyło już znakomicie oswoić model seansów online, a z punktu widzenia strukturalnego jest to obieg o większych zdolnościach adaptacji do już rozpoczętego w branży filmowej kryzysu, który może kosztować wiele instytucji lokalnych życie. Obecna sytuacja wzmaga więc odlokalnianie kina, coraz mocniej zmierzającego w kierunku aktywności głównie umiejscowionej wirtualnie zamiast przestrzennie. Jak do tej pory ma to dwojakie skutki. Z jednej strony skróceniu ulega dystans, dzięki czemu społeczności kultury filmowej mogą łączyć się w sposób spontaniczny i międzykulturowy, nieograniczony przy tym potrzebą fizycznego kontaktu do komunikacji. $\mathrm{W}$ ten sposób kinomani z różnych stron świata zyskują względnie równy dostęp do filmów i towarzyszących im dyskursów, mogą wytwarzać relacje na odległość i w ten sposób dywersyfikować kulturę filmową, łącząc jej fragmenty dotychczas rozwijające się $\mathrm{w}$ opartej na poszczególnych przestrzeniach geograficznych izolacji.

Jednak, na co zwraca uwagę David Harvey (2008: 243), rozwój globalnych sieci kulturalnych wiąże się z ich silną neoliberalizacją i zawierzeniem technokratycznym mechanizmom rynkowym. W tym kontekście wskazać można na zagrożenie, jakim jest zawoalowane w procesie globalizacji wymuszenie na instytucjach, dotąd opierających się na swojej lokalności i w niej tworzonych relacjach społecznych (takich jak przywiązanie widowni do miejsc), działania w grze rynkowej na zasadach podobnych do większych podmiotów o znacznie szerszych możliwościach:

Skoro mamy graczy-gigantów, to oni mogą przetrwać kryzys kosztem mniejszych kin i dystrybutorów. Oni są bardziej w sieci, lepiej się poukładali ze streamingiem, więc mogą kosić konku-

${ }^{20}$ Jeszcze przed pandemią seanse online odgrywały znaczną rolę na rynku filmowym, przede wszystkim za sprawą serwisów streamingowych, takich jak Netflix czy HBO Go, ale też chociażby $\mathrm{w}$ formie prowadzonych przez niektóre festiwale wirtualnych sal skierowanych do widzów spoza fizycznej-realnej przestrzeni wydarzenia. Z rosnącym rynkiem seansów internetowych wiąże się z kolei szereg debat i przemian natury logistycznej, z których bodaj najbardziej wyrazistym przykładem jest spór dotyczący warunków uczestnictwa filmów w konkursach i nominowania do nagród filmów dystrybuowanych wyłącznie w formie online (zob. Porter 2019; Lee 2018). Obecnej sytuacji nie należy więc rozpatrywać w kategorii rewolucyjnej zmiany, wprowadzającej do procesu dystrybucji całkowicie nowy czynnik seansów online, ale jako rodzaj kryzysowego wzmocnienia istniejącego zjawiska czy też po prostu zmianę warunków zewnętrznych, w ramach których funkcjonuje i rozwija się branża. 
rencję [...] Wszystko dąży do ujednolicania i mniejsze kina będą pewnie tracić na znaczeniu, bo mają słabe możliwości dopasowania się w takim stopniu, jak ci duzi ${ }^{21}$.

Stwarzanym przez wirtualizację możliwościom podtrzymywania zachwianych przez izolację praktyk dyskursywnych towarzyszy więc kolejny etap neoliberalizacji rynku, i tak zmagającego się z nierównościami i dominacją wielkich firm „wysysających” rynki lokalne. W tym kontekście sytuacja kryzysowa wzmaga zjawisko „pożerania” lokalności i osadzonych w niekomercyjnych, społecznych aktywnościach fragmentów kultury filmowej przez jej globalizacyjny pęd, wypierający partykularne strategie i przestrzenie kooperacji oddolnej makrokulturą przemysłu rozrywkowego (Lash i Lury 2011).

\section{Opór materii}

Gwałtowny zwrot ku medium internetowemu pociąga za sobą jednak jeszcze pewne efekty uboczne, które sprawiają, że nie da się dostrzec jednoznacznie w liminoidalności izolacyjnej początku totalnej wirtualizacji kultury filmowej. Obok kontynuacji zaangażowania wobec kina, przenoszonego do internetu, wyraźnie zaznacza się pewien opór, częściowo równoważący afirmatywne przechodzenie ku globalnej wirtualności. W związku z nagłym wzrostem intensywności kontaktów z urządzeniami elektronicznymi, wykorzystywanymi szeroko do pracy zdalnej, a także - siłą rzeczy - w większym zakresie jako kanału pożytkowania wolnego czasu, część moich rozmówców zaznaczała problem z przejściem na tryb uczestnictwa oparty na formie online. Wiąże się on z przesytem czasem spędzonym przed ekranem komputera, co zaczyna stanowić pewną barierę dla uczestnictwa w życiu kulturalnym i ogranicza aktywność. Maciej przykładowo stwierdził: „nie potrafię tak oglądać - normalnie chodzę do kina raz do trzech razy w tygodniu, ale teraz rzadko oglądam nawet ten film tygodniowo [...]"22. Dość trafnym określeniem takiego odczucia może być słowo „ekranofobia” - nadmiar obecności komputera, który w izolacji przejął nie tylko rolę ekranu kinowego, ale też biura, sceny teatralnej, przestrzeni wystawienniczych, kawiarni czy barów, powoduje, że wiele osób seanse online traktuje jako niepełny i męczący na dłuższą metę substytut właściwej aktywności. Niektórzy „mają problem, żeby żyć z filmem tak jak normalnie, [ponieważ] ma się wszystko naokoło, kuchnię, sprzątanie, teraz też pracę zdalną... trudno realnie się skupiać na filmie, sali kinowej, wyjścia. [...] Także przy tej izolacji mam zdecydowanie problem, żeby żyć z filmem tak jak normalnie"23. Taka postawa, wiążąca się z mniej lub bardziej bezpośrednim zdystansowaniem wobec formy internetowej życia kinowego - przez niektórych uznawanej wręcz za

\footnotetext{
${ }^{21}$ Rozmowa $\mathrm{z}$ Asią, pracującą w lokalnym kinie studyjnym, przeprowadzona w kwietniu.

22 Rozmowa z Maciejem, krytykiem.

23 Jak wyżej.
} 
„nowy wymiar oglądania filmów”24 - może prowadzić do erozji poczucia związku z kinem jako sferą społeczną. Pozbawienie kina bezpośredniego, organicznego aspektu okazuje się więc, podobnie jak w przypadku teatru, niebagatelnym problemem. Kryzysowy, internetowy model odbioru paradoksalnie zdaje się więc dawać argumenty za niepomijalnym znaczeniem wymiaru fizycznego uczestnictwa w przestrzeni społecznej związanej z kinem i wskazuje na znaczenie pozaestetycznych walorów kina, które bardziej niż forma sztuki wyłania się z przywoływanych wypowiedzi jako pewna domena życia w społeczności i praktykowania siebie jako podmiotu poprzez wchodzenie w relacje z instytucjami oraz innymi ludźmi, bo to „trzyma jakąś tożsamość, teraz stoimy razem w kolejce na przykład. [...] To jest to, co dla mnie trzyma ludzi w kupie, to znaczy te wspólne doświadczenia, że się bierze razem udział w wydarzeniu"25.

Przekłada się to na silnie odczuwaną tymczasowość obecnej sytuacji, w której główny nurt kina stanowi przestrzeń wirtualna, i wyrażaną przez część osób wolę szybkiego powrotu do wcześniejszej formuły aktywności - w tym wspierania wybranych podmiotów, z którymi czuje się więź.

Ja to traktuję trochę jak taką próbę - [...] są instytucje, które mi jakoś robią ten świat filmowy, więc się poczuwam, żeby to jakoś teraz podtrzymywać. Normalnie płacę im za oferty, a teraz to jest wypożyczanie - nawet wczoraj oglądałam drugi raz film, na zasadzie po prostu wsparcia, bo przecież drugi raz do kina bym pewnie nie szła ${ }^{26}$.

Nazwałbym to rodzajem grawitacji ku bezpośredniemu doświadczeniu, która została ujawniona w sytuacji pandemii. Uczestnictwa w kulturze filmowej - jak zresztą chyba w żadnej przestrzeni kulturalnej - nie można sprowadzić jedynie do samego odbioru dzieła artystycznego. Oprócz tego istotną rolę gra także poczucie wspólnoty w ramach pewnego wydarzenia czy definiowanej na styku sfery fizycznej i mentalnej przestrzeni społecznej. Szczególnie widoczne jest to w odniesieniu do festiwali filmowych, których znaczenie i istota w znacznej mierze opierają się na jednostkowej unikalności grupowego uczestnictwa w wydarzeniu o określonym profilu ${ }^{27}$. Oprócz zorientowania wobec kina, które może być z powodzeniem praktykowane $\mathrm{w}$ internecie, wytwarzanie podmiotowości kinomana odbywa się więc również w związku z konkretnymi lokalnymi praktykami - uczestnictwem w unikalnych wydarzeniach oraz poczuciem związku z określoną przestrzenią czy

${ }^{24}$ Cytat pośredni, przytaczany przez Asię, pracowniczkę kina studyjnego.

25 Rozmowa z Agatą, festiwalowiczką-wolontariuszką.

26 Rozmowa z Darią, festiwalowiczką, dorywczo organizatorką DKF.

${ }^{27}$ Same wydarzenia filmowe bywają programowane w taki sposób, by podkreślić ów niepowtarzalny, wspólnotowy charakter, niemożliwy do odtworzenia w wariancie zdalnym - chociażby przez projektowanie specjalnych pokazów angażujących widownię - np. organizowane przez grupę VHS Hell pokazy filmów „klasy Z” (czyli powszechnie uznawanych za złe do stopnia, w którym widz czerpie perwersyjną przyjemność z nieudolności artystycznej) z improwizowanym na żywo tłumaczeniem, pokazy filmów interaktywnych czy popularne na części festiwali organizowanych w okresie letnim seanse pod gołym niebem. 
instytucją. Są to elementy budujące tożsamości widzów, które nie mogą być łatwo przeniesione do modelu uczestnictwa online, co stanowi swoistą przeciwwage wobec otwieranych przez ten model możliwości szerszego dostępu do kina. Krytyczna (auto)refleksja w odniesieniu do postępującej wirtualizacji stanowi więc rodzaj oporu „pożeranej” lokalności i jednostkowości doświadczenia kinowego, wywołany przebodźcowaniem, efektem ubocznym. Poddany presji zewnętrznej, wymiar lokalny kina ulega aktywizacji za pośrednictwem gry braku i przesytu, w czym upatrywałbym przynajmniej potencjalnej rekonstytucji materialnej ontologii kina, a w konsekwencji - podkreślenia dualistycznego charakteru kultury filmowej, która nie będzie ulegać zbyt szybko oderwaniu od swojego zakorzenienia w kontakcie międzyludzkim.

\section{Dwa oblicza wirtualizacji}

Z perspektywy widzów technologiczny wymiar filmu, związany z jego postępującą wirtualizacją, jawi się w sposób złożony i co najmniej ambiwalentny. Trudno przeoczyć czy zdyskredytować perspektywy rozwoju kina i tworzonych wokół niego społeczności, jakie otwiera proces wirtualizacji - przekraczanie ograniczeń przestrzennych i związane $\mathrm{z}$ nim wytwarzanie nowych, nierzadko niezwykle ciekawych i płodnych, tworzących relacje i emancypujących wielokulturowość, pól dyskursu stwarza szerokie możliwości rozwoju kultury filmowej w kierunku wyrastającej ze spontanicznych i nieinteresownych kontaktów sieci międzynarodowej i międzykulturowej, dzięki której częściowo przekraczane mogą być partykularyzmy regionalne, a w konsekwencji - przynajmniej potencjalnie - obraz globalny kultury filmowej ulegać może dywersyfikacji. Z drugiej strony jednak ta trajektoria rozwoju ma niewątpliwe ciemne strony w postaci silnego związku z korporacyjnym kapitałem, kontrolującym i moderującym kanały oddolnych, interkulturowych przepływów komunikacji. W obliczu postępującej wirtualizacji dystrybucji, a także życia filmowego, widzowie skazywani są na zależność od technologii, a erozji mogą ulegać bezpośrednie, organiczne kontakty, tworzące wokół kina społeczności i więzi. Praktyki dyskursywne wobec kina okazują się więc o tyle elastyczne, że podatne na tworzenie hybrydowych form wiążących realne aktywności z przestrzenią wirtualną, jednak przy tym dość trwale osadzone w materialności kontaktu, by wywoływać reakcję-poczucie braku w sytuacji pandemicznego zamrożenia rynku.

Powyżej przedstawiona analiza wpisuje się w znacznie szerszą problematykę związaną ze społecznym usytuowaniem kina i odnosząc się do określonego wycinka czasu oraz zawężonej perspektywy pragmatycznej, ma charakter z de- 
finicji fragmentaryczny. Sytuacja zmienia się bardzo szybko ${ }^{28}$, dlatego też moim celem było przede wszystkim naszkicowanie pewnej dynamiki, jaką eksponuje pandemia w odniesieniu do kultury filmowej, i wskazanie na pojawiające się na poziomie widzów filmowych poglądy i reakcje na zaistniałą sytuację. Jest to w zasadzie przyczynek do dalszych rozważań na temat charakteru współczesnego kina jako aktora społecznego i procesów związanych z globalizacją oraz rozwojem nowych technologii, a co za tym idzie, coraz to nowych kanałów dystrybucji filmów i komunikowania o nich. Do zbudowania takiego pogłębionego studium konieczne jest jednak solidne etnograficzne rozpoznanie poszczególnych cząstek całego zespołu zjawisk, fragmentów kultury filmowej oraz wyróżniających się epizodów jej funkcjonowania. Na podstawie ich zrozumienia stopniowo można dochodzić do ogólnego rozumienia specyfiki społecznego bytu kina.

\section{Bibliografia}

\section{Adorno T.}

1990 Podsumowanie rozważań na temat przemystu kulturowego, w: tegoż, Sztuka i sztuki, przeł. K. Krzemień-Ojak, Warszawa, s. 13-20.

Bourdieu P.

2007 Reguly sztuki: geneza i struktura pola literackiego, Warszawa.

Ellis C., Adams T.E., Bochner A.P.

2011 Autoethnography: An overview, „Forum: Qualitative Social Research” nr 12(1), art. 10, www.qualitative-research.net/index.php/fqs/article/view/1589/3095 (dostęp: 8.05.2020).

Goi L.

2020 The Current Debate: Film Festivals in the Time of Coronavirus, „Mubi”, https:// mubi.com/notebook/posts/the-current-debate-film-festivals-in-the-time-of-coronavirus?fbclid=IwAR2gZ8MywIgBb-mnfVcspWrActs93MH4g0G7JSz0Lma4eCidR1wLziBJO5A (dostęp: 5.05.2020).

Gupta A., Ferguson J.

1997 Beyond "Culture": Space, Identity and Politics of Difference, w: Culture, Power, Place: Explorationa in Critical Anthropology, A. Gupta, J. Ferguson (red.), DurhamLondon, s. 33-51.

Hansen M.B.

2012 Cinema and Expierience. Siegfried Kracauer, Walter Benjamin and Theodor Adorno, Los Angeles-Londyn. „IndieWire”

20.05.2020 Coronavirus Cancellations: Every Film, TV Show, and Event Affected by the Outbreak, https://www.indiewire.com/feature/coronavirus-cancellations-hollywood-entertainment-covid19-1202215596/ (dostęp: 20.05.2020).

${ }^{28} \mathrm{~W}$ momencie składania artykułu do druku większość krajów europejskich przeprowadza stopniowe odmrażanie gospodarki, w reżimie sanitarnym działają m.in. kina i inne instytucje. 
Kafar M.

2002 Rozważania o antropologii Victora Wittera Turnera, „Lud”, t. 86, s. 13-29.

Kracauer S., 1997 Theory of Film. The Redemption of Physical Reality, Princeton.

Kracauer S., 2012 Toward a Theory of Film, w: American Writings. Essays on Film and Popular Culture, J. v. Moltke, K. Rawson (red.), Los Angeles-Londyn, s. 199-225.

Lash S., Lury C.S.

2011 Globalny przemysł kulturowy. Medializacja rzeczy, przeł. J. Majmurek, R. Mitoraj, Kraków.

Latour B.

2005 Reassembling the Social. An Introduction to Actor-Network Theory, New York. Lee $\mathrm{B}$.

2018 Netflix pulls out of Cannes film festival after rule change, „The Guardian” 11.04.2020, https://www.theguardian.com/film/2018/apr/11/netflix-pulls-out-cannes-film-festival (dostęp: 13.07.2020).

Porter J.

2019 The Academy won't change its rule to exclude Netflix from Oscars, „The Verge" 24.04.2019, https://www.theverge.com/2019/4/24/18514430/oscars-netflix-amazon-prime-academy-awards-entry-rules-nominations-spielberg-roma (dostęp: 13.07.2020).

Pulver A.

2020 Cannes film festival says 2020 edition cannot go ahead 'in original form', „The Guardian" 14.04.2020, https://www.theguardian.com/film/2020/apr/14/cannes-film-festival-says-2020-edition-cannot-go-ahead-in-original-form (dostęp: 8.05.2020).

Rabinow P., Marcus G.E., Faubion J.D., Rees T.

2008 Designs for an Anthropology of the Contemporary, Durham-London.

Stolworthy J.

2020 Cannes Film Festival update: Event not cancelled but unlikely to take place, according to insider, „Independent” 14.03.2020, https://www.independent.co.uk/arts-entertainment/films/news/cannes-film-festival-cancelled-coronavirus-france-announcement-event-delayed-films-2020-a9402386.html (dostęp: 5.05.2020).

Turner G.

1999 Film as Social Practice, London-New York.

2002 Editor's Introduction, w: The Film Cultures Reader, G. Turner (red.), London-New York, s. 1-11.

Turner V.

2005 Gry społeczne, pola i metafory. Symboliczne działanie w społeczeństwie, przeł. W. Usakiewicz, Kraków.

Żygulski K.

1970 Kultura filmowa w Polsce, „Kino” nr 7, http://akademiapolskiegofilmu.pl/pl/historia-polskiego-filmu/artykuly/kultura-filmowa-w-polsce/243 (dostęp: 20.05.2020) 